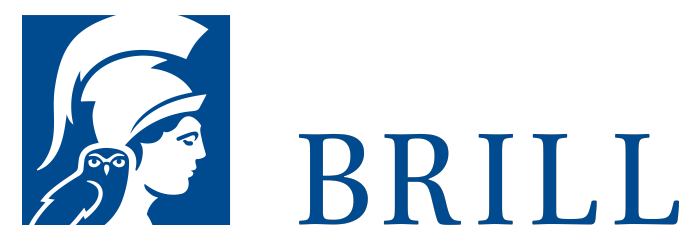

\title{
Jeremiah's Scriptures
}

Production, Reception, Interaction, and Transformation

Editors: Hindy Najman and Konrad Schmid

Jeremiah's Scriptures focuses on the composition of the biblical book of Jeremiah and its dynamic afterlife in ancient Jewish traditions. Jeremiah is an interpretive text that grew over centuries by means of extensive redactional activities on the part of its tradents. In addition to the books within the book of Jeremiah, other books associated with Jeremiah or Baruch were also generated. All the aforementioned texts constitute what we call "Jeremiah's Scriptures." The papers and responses collected here approach Jeremiah's scriptures from a variety of perspectives in biblical and ancient Jewish sub-fields. One of the authors' goals is to challenge the current fragmentation of the fields of theology, biblical studies, ancient Judaism. This volume focuses on Jeremiah and his legacy.

Readership

All interested in the composition of Jeremiah, the place of Jeremiah in the Hebrew Bible and its relationship with Deuteronomistic history and theology, and Jeremianic interpretation in Christianity and Judaism.

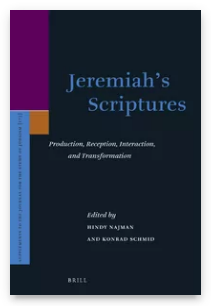

Language:

English

Subjects:

General, Jewish

Studies, Biblical

Interpretations,

Biblical Studies,

Hebrew Bible,

Biblical Studies,

Dead Sea Scrolls,

Biblical Studies,

Ancient

Judaism, Biblical

Studies

Publisher: Brill

Series:

Supplements to

the Journal for

the Study of

Judaism,

Volume: 173

E-Book (PDF)

Released online:

o5 Oct 2016

ISBN: 978-9O-

04-32025-3

List price

USD $\$ 263.00$

\section{Hardback}

Publication date:

15 Nov 2016 
Hindy Najman, Ph.D. (1998), Harvard University, is the Oriel and 04-32O24-6

List price Laing Professor of the Interpretation of Holy Scripture at the University of Oxford. She has published monographs and numerous articles on biblical interpretation, history of scholarship and revelation, including Losing the Temple and Recovering the Future: An Analysis of 4 Ezra (Cambridge University Press, 2014).

Konrad Schmid, Ph.D. (1995), University of Zurich, is Professor of Hebrew Bible and Ancient Judaism at that university. He has published Buchgestalten des Jeremiabuches (WMANT 72;

Neukirchen-Vluyn: Neukirchener, 1996) and he is working on a commentary on the book of Jeremiah.

For more information see brill.com

\footnotetext{
Order information: Order online at brill.com +44330 333 o049 | customerservices@brill.com Submission information: brill.com/authors
} 